\title{
VÁROSREHABILITÁCIÓS BEAVATKOZÁSOK ÉS A TÉRBELI TÁRSADALMI KIREKESZTÉS: A TÁRSADALMILAG FENNTARTHATÓ VÁROS- FEJLŐDÉS BUDAPESTI LEHETŐSÉGEI ${ }^{1}$
}

\author{
(Intervention of Urban Rehabilitation and Spatial Social \\ Exclusion: Possibilies of Socially Sustainable \\ Urban Development in Budapest)
}

KOVÁCS ZOLTÁN - SZIRMAI VIKTÓRIA

Kulcsszavak:

városrehabilitáció társadalmi kirekesztés társadalmilag fenntartható fejlödés európai folyamatok nagyvárosi problémák budapesti helyzetkép

A tanulnányból kiderülnek a társadalmi fenntarthatóság koncepciojának a bevezetését igényló európai nagyvárosi problémák, illetve a Budapestre jellemzö térbeli társadalmi kihívások, a tärsadalmilag fenntartható városfejlödés bevezetésének mai akadályai. Az elemzések feltárják a Budapesten eddig megvalósitott városrehabilitációs modellek föbb tärsadalmi következményeit, az érintett városrészek lakosságának kicserélödését, a dzsentrifikációt, a szegregációs folyamatok élezödését. A tanulmány javaslatokat is tesz a tärsadalmilag fenntartható värosrehabilitáció megalapozása érdekében.

\section{Bevezetés}

A 2005-ös franciaországi szegénynegyedek lázadásai egyértelmủen bizonyítják, hogy a térbeli társadalmi kirekesztés problematikája a mai Európa egyik legfontosabb, komplex kezeléseket igénylö kihívása. A városi társadalmi kirekesztés a globális kapitalizmus müködéséböl fakadó társadalmi következményeket, a globális urbanizáció területi hatásait, s ennél fogva a térbeli társadalmi egyenlötlenségek új paradigmáját fejezi ki. Az új paradigma értelmében meghatározott társadalmi helyzetben lévő emberek, többnyire az alacsony iskolázottságú, szakképzetlen társadalmi csoportok, az idősek, az alacsony státuszú bevándoroltak és etnikai kisebbségek nemcsak a társadalom alapmúködését biztositó gazdasági tevékenységekböl (a munkaeröpiacról), de az abból adódó társadalmi szerepekböl, az oktatási rendszerből, valamint a teljes emberi életet biztosító lakóhelyi körülményekböl is ki vannak rekesztve.

A francia elővárosi konfliktusok alapvetően társadalmi strukturális problémák megnyilvánulásai, az elővárosokban koncentrálódó hátrányos helyzetủ csoportok társadalmi-gazdasági nehézségeit, a globalizáció kedvezőtlen gazdasági hatásai miatti kilátástalan helyzetét mutatják. A francia elővárosi lázadások a nemzeti bevándorlási politika, a francia integrációs modell diszfunkcionális múködését, illetve a nem megfelelö, kirekesztő várospolitikai beavatkozások következményeit 
Kovács Zoltán - Szirmai Viktória : Városrehabilitációs beavatkozások és a térbeli társadalmi kirekesztés :

A társadalmilag fenntartható városfejlődés budapesti lehetőségei. Tér és Társadalom 20. évf. 2006/1. 1-19. p.

is kifejezik. Az 1950-es években, az 1960-as évek közepén, a föként észak- és nyugat-afrikai bevándoroltakat a nagyvárosok, közte Párizs elóvárosaiban, perifériáján közpénzekböl kialakított bádogvárosrészekben, az ún. bidon-villekben, az 1970-es évek derekától a Párizs, illetve nagyváros környéki elövárosi lakótelepek szociális lakásaiban telepítették le. Ezekböl a szegregátumokból - ahol a városi átlagnál jóval magasabb munkanélküliség nemcsak a bevándoroltakat, hanem az ott élö francia lakosságot is súitja - a későbbi generációk sem tudtak kitörni. A franciaországi elővárosok mai lázadásai mérföldkőnek számítanak, mert bizonyítják, hogy a társadalmi kirekesztés következtében létrejött területi szegregáció akadályozza a széleskörü társadalmi integrációt, a lokális társadalmi kohéziót, egyben jelzik, hogy a társadalmi kirekesztés országhatárokat is átlépó társadalmi konfliktusokat okozhat. A párizsihoz hasonló lázadások egyéb francia és más európai nagyvárosokban is létrejöttek.

Az európai elővárosi konfliktusok a globális urbanizációban, a városfejlődés különböző szakaszaiban eltérő módon szerveződő térbeli társadalmi kirekesztôdést okozó folyamatokat, közte a témánk szempontjából kiemelten fontos városrehabilitációs beavatkozások kedvezőtlen hatásait, ha nem is minden esetben fejezik ki, de sok szempontból szimbolizálhatják. A nyugat-európai városokban az 1970-es, 80-as években kezdték felújítani a belvárosokat, a belvárosokat környező negyedeket, közte a fizikailag lepusztult és társadalmilag marginalizálódott slumokat. A felújítást követő urbanisztikai átalakulások, a megnövekedett ingatlan- és telekárak, valamint a kirekesztést támogató várospolitikai döntések miatt az alacsony társadalmi státuszú csoportok kiszorultak a városszéli negyedekbe, közte a rossz minőségủ lakótelepekre is. Bár a francia elővárosok szegregációját nem a belvárosok felújítása, hanem átfogó várospolitikai döntések, szegregációt eredményező letelepítési politikák okozták, a belső részekben megvalósuló felújitások a kiszorítási problémákat nyilvánvalóan felerősítették, új irányokba is terelték. A francia esetben az afrikai bevándorlók elővárosi lakótelepi elhelyezése miatt egyrészt felgyorsultak a belvárosi dzsentrifikációs folyamatok, hiszen a bevándoroltak letelepedését követően a francia középosztály nagy része elhagyta a lakótelepeket és a jobb negyedekbe, közte a belvárosba, illetve a Párizs környékén fejlesztett új városokba költözött. Az elővárosi társadalmi problémák arra hívják fel a figyelmet, hogy a térbeli társadalmi problémák szigetszerủ kezelése csupán a problémák területi áthelyeződését és nem a megoldását adják. A belvárosi rehabilitációk (a francia példa esetében a városközpontot kímélni törekvő telepítési várospolitikák) a városközpon-tok társadalmi problémáit ugyan enyhítették, többnyire felszámolták (vagy megelözték) az ott megjelent szegénységet, de a komplex strukturális és területi kezelések hiánya miatt a területi társadalmi problémák a városok más részein jelentek meg.

Nyugat-Európában, a belvárosokban és azok peremén megmutatkozó fizikai és társadalmi válságjeleket, a városközpontok és a külsô zónák társadalmi polarizációját, a városi szegénység és a társadalmi kirekesztés területi megnyilvánulásait az 1990-es évek óta a társadalmi fenntarthatóság koncepciójának alkalmazásával igyekeznek kezelni. A koncepció számos lokális probléma megoldására adott lehetőséget, jóllehet a széleskörủ megvalósulást ugyan sok minden akadályozza. Az ered- 
Kovács Zoltán - Szirmai Viktória : Városrehabilitációs beavatkozások és a térbeli társadalmi kirekesztés :

A társadalmilag fenntartható városfejlődés budapesti lehetőségei. Tér és Társadalom 20. évf. 2006/1. 1-19. p.

mények azért is jelentősek, mert az 1990-es évek átalakulása során egyértelmüvé vált, hogy a kelet-közép-európai városokban is fölerősödtek a fizikai és társadalmi problémák, gyorsult a társadalmi polarizáció. Ezzel egy időben a társadalmi kirekesztés térbeli folyamatai is felerösödtek, $s$ minden jel arra utal, hogy a globális trendekben, közte a nyugat-európai városfejlődési folyamatokban megfigyelt belvárosi társadalmi problémák a mai kelet-közép-európai városfejlödésben is relevánsak. Szükség lehet tehát a poszt-szocialista országokban is a nyugat-európai városokban alkalmazott társadalmilag fenntartható városfejlődés koncepciójának az alkalmazására.

\section{A társadalmilag fenntartható városfejlödés értelmezése}

A társadalmi fenntarthatóság gondolata elsőként a Brundtland Reportban (1987) jelent meg. A világ nagy problémáit elemző jelentés rámutat a fejlödő országokban érzékelhető, kezelhetetlen városnövekedési folyamatokra, az állandóan növekvő lakóhelyi igényekre, a koncentrált városfejlődés problémáira, köztük a városi szegénység, a betegségek okozta gondokra. Az iparosodott országok városai esetében elsösorban a belvárosok leromlása, a nagy városfejlesztési beavatkozások kedvezötlen társadalmi hatásai, a városi szegénység új formái jelentenek kihívást. A problémák megoldása érdekében a jelentés javaslata az, hogy a „gazdasági növekedés új korszakára van szükség, amely erőteljes, de társadalmilag és környezetileg fenntartható" (Brundtland 1987, 18).

A Brundtland jelentésben megfogalmazott társadalmi fenntarthatósági gondolatot a Környezet és Fejlödés Világkonferencia (Rio de Janeiro, 1992) tette általánosan elfogadott törekvéssé. A konferencia legnagyobb jelentőségét az adja, hogy rámutatott a globális szintú közös stratégia, közös jövőkép kialakításának a fontosságára, valamint hogy felvetette a jövő nemzedék érdekei képviseletének a szükségességét is (Tamás 2006).

A tanulmány felfogása szerint a társadalmilag fenntartható városfejlödés abban különbözik a fenntartható városfejlödés fogalmától, hogy nagyobb hangsúlyt ad a társadalmi szempontok védelmének, hogy a környezeti, a gazdasági és a társadalmi érdekek érvényesítésének a komplexitását hangsúlyozza. Erre azért is szükség van, mert a társadalmilag fenntartható koncepció általában kevesebb figyelmet kap, mint a környezetileg fenntartható fejlödés (Hancock 2004). Ez az értelmezés megegyezik a Brundtland jelentés felfogásával is. A koncepció demokratikus és szolidaritást sugalló, az összes érintett és érdekelt társadalmi szereplö - helyzetéböl fakadóan differenciált - anyagi részvételét feltételezi, a nemzetközi, a nemzeti, a helyi kormányzatok, a közösségi és a magán szektor, a gazdasági vállalkozások, az egyének, a nonprofit szektor forrásaira alapozott összefogás jelentöségét képviseli (Soóki-Tóth 2005).

A társadalmilag fenntartható városfejlődés jövöképében a városfejlesztési források igazságos elosztása valósul meg, amely a városi népesség fizikai, mentális, gazdasági és társadalmi jólétét egyaránt szolgálja. A hivatalos politika támogatja az oktatást és a humán potenciál fejlesztését egyaránt. A várospolitika védi az építészeti, a kulturális és a társadalmi örökséget. A várospolitikai rendszer biztosítja a 
Kovács Zoltán - Szirmai Viktória : Városrehabilitációs beavatkozások és a térbeli társadalmi kirekesztés :

A társadalmilag fenntartható városfejlődés budapesti lehetőségei. Tér és Társadalom 20. évf. 2006/1. 1-19. p.

városlakók részvételét a helyi politikákban és a városfejlődést befolyásoló döntésekben, a rehabilitációs projektekben. A politika támogatja, védi és fejleszti a társadalmi kohéziót, törekszik a városfejlesztéssel összefüggő érdekek feltárására, egyeztetésére, az érdekek harmonizálására, ami a társadalmi részvétel elvén alapszik. És végezetül a hivatalos politika megakadályozza a társadalmi kirekesztést, szolidáris a társadalmi okokból hátrányos helyzetủ, kiszolgáltatott csoportokkal, és biztosítja a különbözö társadalmi csoportok, eltérő közösségek és kultúrák együttélését.

Ez a fajta várospolitika csak akkor valósulhat meg, ha összhangban van a városi társadalom értékrendjével és lakóhelyi elvárásaival. A feltételek biztosításának és a megvalósulásnak az összhangját, a várospolitika és az érintett társadalmak kölcsönös párbeszéde, az ehhez szükséges intézményrendszer biztosíthatja. Miközben nyilvánvaló, hogy még a legdemokratikusabb várospolitika sem elegendő önmagában a térbeli társadalmi problémák megoldására. A városban koncentrálódó társadalmi fenntarthatósági problémák megoldásai strukturális (munkaerö-piaci, oktatási, szociálpolitikai stb.) és lakóhelyi (komplex fizikai és társadalmi városfelújitási) beavatkozásokat is megkövetelnek.

A társadalmilag fenntartható városfejlödés megalapozása a kelet-közép-európai városokban kiváltképp nehéz folyamat, az ahhoz szükséges tényezök sokkal kevésbé kialakultak, mint a fejlett nyugat-európai társadalmakban (Fleischer 2002). Nem megfeleló a várospolitika és a civil társadalom, az őket képviselö civil szervezetek viszonya. Még mindig nem jellemző a fejlett, környezettudatos civil társadalom, kevés az erős, környezeti érdekérvényesítésre képes civil társadalmi szervezet. A társadalmi polarizáció éleződése, a szegénység növekedése miatt a (környezetet károsító) munkahelyek védelme (is) kiemelt szempont az alacsonyabb társadalmi státuszúak körében, a közép- és felsőbb osztályok értékrendje fogyasztás centrikus, s ez sokszor károsítja a természeti környezetet (Szirmai 1999).

Változást a társadalmilag fenntartható városfejlödés meglapozásában érdekelt és érintett társadalmi szereplök, a civil mozgalmak, a nemzetközi, a nemzeti és helyi szakmacsoportok és önkormányzatok megerösödése, a mainál sokkal megalapozottabb együttmüködése hozhat.

\section{Társadalmi fenntarthatóság problémái Európában}

Európában a társadalmi fenntarthatóság koncepcióját alapvetően a belvárosokban és a belvárosok peremén megmutatkozó fizikai és társadalmi válságjelek, a városközpontok és a külső zónák társadalmi polarizációja, a modern nagyvárosi szegregáció folyamatai és a városi szegénység, a társadalmi kirekesztettség területi konfliktusai hívták életre.

A belvárosokra jellemző válságjelek történetileg elsöként az amerikai nagyvárosokban jelentkeztek. A 19. század végén felgyorsult városfejlödés, a gazdaság és a népesség gyors nagyvárosi koncentrációja, a vidéki népesség városi, belvárosi terekbe áramlása, a népességnövekedés és az infrastrukturális fejlödés közötti szakadékok kialakulásához vezetett. A belső városrészekben található épületek gyors romlásnak 
Kovács Zoltán - Szirmai Viktória : Városrehabilitációs beavatkozások és a térbeli társadalmi kirekesztés :

A társadalmilag fenntartható városfejlődés budapesti lehetőségei. Tér és Társadalom 20. évf. 2006/1. 1-19. p.

TÉT XX. évf. 2006 -1

Városrehabilitációs beavatkozások és a ...

5

indultak, a lakásállomány egyre nagyobb mértékben pusztult, a környezeti problémák, a zaj, a közlekedési gondok az ott élök számára elviselhetetlenné váltak. A fizikai leromlást társadalmi jelenségek és konfliktusok követték. A jelzett okok miatt a tehetösebb csoportok elmenekültek a belső negyedekből, miközben megindult a társadalom perifériáján lévố rétegek beáramlása, az alacsonyabb társadalmi státusú csoportok, hátrányos helyzetben lévő etnikai csoportok koncentrációja. Jellemzỏvé váltak a deviáns társadalmi jelenségek, a prostitúció, a kábítószer fogyasztás, a szervezett bünözés (Hoyt 1973, 163).

A belváros válsága nem kizárólagos magyarázata annak, hogy a múlt század harmincas éveitól kezdve az addig koncentrált városnövekedés a centrumokból áttevödött az elővárosokba. A gazdaság dekoncentrációja, a városközpontok funkcionális átalakulása, a motorizáció, a gépkocsi forgalom fellendülése, az elỏvárosi bevásárlóközpontok terjedése, a középosztály jövedelmi viszonyainak emelkedése és új lakóhelyi elvárásai ugyancsak hozzájárultak a jelenség kialakulásához (Timár 1999).

Európában az 1950-es, 60-as években gyorsult fel a társadalom dekoncentrációja, a nagyvárosi népesség majd a gazdaság kifelé törekvése. Bár az európai városfejlödés soha nem hozott létre az amerikai városokra jellemzö mértékú belvárosi válságot, itt is érzékelhetővé vált a várospusztulás jelensége. Az európai középosztálybeliek soha nem utasították úgy el a belső városrészeket, ahogy az amerikai jómódú rétegek tették. A belvárosban lakni mindig érték maradt, az épített környęezet színvonala, történelmi értékei miatt is. Az európai országokban soha nem jött létre az amerikai méreteket öltő személygépkocsi forgalom, a kisebb távolságok és a fejlett tömegközlekedés miatt sem.

Az 1970-es évektöl a poszt-fordi gazdaság megerösödésével fokozatosan új városi társadalmi szerkezet jött létre. A szuburbanizáció a centrum városok „strukturális deficitjével", vagyis azzal járt, hogy a magas jövedelmü csoportok a városok szegélye felé mozdultak, miközben az alacsonyabb jövedelműek a belsö részekben maradtak (Innovative Policies... 1996; Territorial Development... 1999). Ez a folyamat a hetvenes években a nagyvárosi régiók nagyfokú elnéptelenedését, vagyis a dezurbanizáció lehetöségét mutatta. Az 1970-es, 1980-as években felgyorsult a bevăndorlás folyamata is. Az afrikai és ázsiai országokból érkezett vendégmunkások a központokhoz közeli leromlott városrészekben, munkásnegyedekben helyezkedtek el (Hermann-Leuthold 2005). (Svájcban voltak olyan belváros közeli városrészek, ahol a külföldiek aránya 50\% volt [Hermann-Leuthold 2005].) A nyugateurópai nagyvárosokban mindenhol szaporodtak a hátrányos életlehetöségeket nyújtó, marginális vagy deviáns élethelyzetekre szocializáló, a társadalmi problémákat és konfliktusokat koncentráló, a társadalmi integrációt nem vagy alig biztosító, leromlott belsó városrészek (Berger 1998, 269-283).

Az 1990-es évek a területi társadalmi-gazdasági folyamatok új irányait hozták létre. A fejlett nyugat-európai országokban (de az Egyesült Államokban is) megfigyelhetỏ volt a gazdasági és társadalmi élet (ismételt) koncentrációja, a globális tőke és annak intézményei, a transznacionális vállalatok, a szolgáltató szektor, a szakképzett munkaerö nagyvárosi sürüsödése (Sassen 1991, 17-35; Veltz 1996, 33). A globális 
Kovács Zoltán - Szirmai Viktória : Városrehabilitációs beavatkozások és a térbeli társadalmi kirekesztés :

A társadalmilag fenntartható városfejlődés budapesti lehetőségei. Tér és Társadalom 20. évf. 2006/1. 1-19. p.

gazdaság igényei a belső városmagok funkcióváltását, a korábbi lakóhelyi funkciók igazgatási, ủzleti funkciókká alakulását hozta. Ennek nyomán az európai belvárosokban számos rehabilitációs beavatkozás történt. Ezek a folyamatok a globalizáció, a globális gazdaság városközpontok iránti igényeit, a globális gazdasághoz kapcsolódó társadalmi rétegek belvárosi lakóhelyi törekvéseit is kifejezték. A kutatások szerint a világpozíciókat birtokló cégek és az azokhoz kapesolódó ún. új technokrácia, tehát a magas jövedelmủ menedzserek, magasan képzett szakmacsoportok, tőkerésszel rendelkezö alkalmazottak a városközpontokban, míg a rutinszerủ munkát végzỏk, a nemzeti vállalatok alkalmazottai és a nemzeti középosztály tagjai a városrégiók perifériáin, jobb minőségủ elővárosaiban helyezkednek el (Sassen 1991, 245-322). A jelzett új szegregációs trendek, a „gentrification”, vagy az „enbourgeoisement”, a belvárosi negyedek ismételt polgárosodását hozták.

Ez a ma még nem számottevő méretủ, de növekvő létszámú csoport a városi társadalmi szerkezetet jellegzetes módon határozza meg. Ök a ,metropolitan businessmen", a transznacionális középosztály tagjai, a nemzetközi szakértök, a müvészeti és média élet, az európai kormányok, nemzetkőzi szervezetek képviselöi, a tudás alapú szolgáltató szektor fejlődésének a produktumai. Ezek a csoportok nemcsak egy vărosban, hanem szinte a városok között élnek, ők használják elsősorban a városközpontokban található szolgáltatásokat, a hoteleket, az éttermeket, ỏk látogatják a kulturális élet nagyobb eseményeit (Martinotti 2004).

Az 1990-es évek óta az európai városok társadalmi szerkezetét a dzsentrifikáció, és a marginalizáció komplementer, egymást kiegészítỏ ellentmondásos folyamatai alakítják. A dzsentrifikáció folyamatai föként a centrumra, a centrum közeli részekre, a történelmileg jobb módúak által lakott negyedekre (az ún. „Beaux Quartiers”re) és a jobb elővárosokra vonatkoznak, míg a marginalizáció inkább a perifériákra jellemzö (Hermann-Leuthold 2005, 4). A belvárosok megújulását követően az 1950-es, 1960-as években épuilt, pusztulófélben lévő városszéli lakótelepekröl a jobb módú, képzettebb rétegek is a belső részekbe költỏztek. A helyüket egyre több idős, alacsony státuszú bevándorolt, deprivált helyzetủ foglalta el. Ezzel létrejött a modern vărosi társadalmak egy új térbeli társadalmi egyenlőtlensége, a jól képzett, magas jövedelmủ, modern városi középosztály által lakott városcentrumok és az alacsonyan iskolázott, szakképzetlen, a városi társadalomhoz kevésbé integrált város perifériák megosztottsága (Hermann-Leuthold 2005, 12).

A kelet-közép-európai országokban - az államszocializmus idején - a szabad piac és a magántöke hiánya, ill. az állam mindenre kiterjedő befolyása megakadályozta az urbanizáció piac és fogyasztás vezérelte, új térfolyamatainak kialakulását (Enyedi 2003; Kovács 2002). Bár az 1970-es évekre ezekben az országokban is nyilvánvalóvá váltak a belvárosi problémák, a történeti mủemlékek, a lakásállomány pusztulása, a slumosodás folyamata, a természeti környezeti károk. Az állami beavatkozás nyomán a fizikai leromlás társadalmi következményei azonban jóval kisebb mértékben jelentek meg a kelet-közép-európai térség városaiban, mint a korabeli nyugat európai városokban. 
Kovács Zoltán - Szirmai Viktória : Városrehabilitációs beavatkozások és a térbeli társadalmi kirekesztés :

A társadalmilag fenntartható városfejlődés budapesti lehetőségei. Tér és Társadalom 20. évf. 2006/1. 1-19. p.

A kelet-közép-európai városokban a szuburbanizáció is sokkal kevésbé volt érzékelhetö, mint a nyugat-európai városokban (Musil 2002). Ebben a lakáspiac korlátozása, a szigorú tervezési kontrol éppúgy közrejátszott, mint a motorizáció alacsonyabb szintje, amely megkívánta, hogy a munkaerö és a munkahelyek a térben viszonylag szorosan egymás mellé rendeződjenek, kettőjük térbeli elszakadására nem voltak meg az infrastrukturális adottságok (pl. autópályák, sủrủ elővárosi vasúthálózat). Bár a középosztály tömeges városszéli kivonulásáról még nem lehetett beszélni, az állami lakáselosztási mechanizmusok, az új lakótelep-építkezések lehetővé tettek egyfajta „kvázi-szuburbanizációt”. A lakótelepi társadalmak, sok esetben a leromlott belső városrészek tehetösebb, jobb politikai érdekérvényesítési lehetỏségekkel, magasabb pozícióval rendelkező társadalmi rétegeinek városszéli kivonulásának voltak az eredményei.

A kelet-közép-európai városok történelmi belvárosainak a fizikai, társadalmi problémái részben az államszocialista örökséggel magyarázhatók. A városközpontok fejlesztése nem vagy csak kis mértékben volt része a várospolitikáknak (Lichtenberger et al. 1995). Ideológiai értelemben a városközpont konzervatív, burzsoá jelenség volt, ezért nem kapott prioritást a fejlesztési döntésekben. Politikai, ideológiai célok, a munkásság lakáshelyzetének a megoldási törekvései, a mennyiségi lakáshiány kezelésének céljai (továbbá a nagy építőipari cégek, a házgyárak érdekviszonyai) is magyarázták, hogy a városfejlesztésekben kiemelten fontos volt a lakótelepek fejlesztése. Az infrastrukturális fejlesztési források lakótelepi felhasználása miatt hiányoztak, vagy csak szigetszerủen, pontszerúen jöttek létre az állam, illetve a helyi önkormányzatok által megvalósított rehabilitációs programok és fejlesztések. A belvárosi válság enyhítését akadályozták az államszocialista rendszerek egyre élesebbé váló válságjelei, a gazdasági nehézségek is.

Az 1990-es évek jelentős változásokat eredményeztek. Ezek a változások azonban nagyon ellentmondásos módon játszódtak le, a városközpontok meghatározott részeinek gyors és látványos fejlődésével, más részek leszakadásával, fokozatos pusztulásával. Az átalakulás kedvező jelenségei a city-képződés folyamataiból, az üzleti, kereskedelmi funkciók növekedéséből fakadnak. Ennek keretében minden nagyobb városban jellemzỏ a pénzintézmények, bankok, irodaházak építése, új vagy megújuló gazdasági, kereskedelmi centrumok és a kapcsolódó infrastruktúrák kialakítása, szállodák felújítása, ill. újak építése, bevásárlóközpontok kialakítása, üzleti-piaci alapú ingatlanfejlesztések. A városközpontokat modernizálják az elegáns üzletek, új éttermek és kávéházak, sétáló utcák, turisztikai látványosságok, új funkciókkal töltik meg a történelmi városrészeket. A belső városrészek, az új építészeti megoldások a globális, illetve a nyugat-európai nagyvárosok hangulatát idézik. Ennek oka, hogy a városnegyedek urbanisztikai átalakulása egyre erőteljesebben függ a globális gazdaság terjedésétöl, lokális hatásaitól, mint a nemzetgazdaság befolyásától (Szirmai-Baráth 2005).

A belvárosi lakónegyedekben is mélyreható átalakulás ment végbe. Ez azzal is összefügg, hogy az állami lakások privatizációját követően jellemzö trenddé vált a belvárosi lakások irodákká alakulása, a lakások irodai funkciókra történő bérbeadása, a mindezt megelőző épület felújítások is. Megfigyelhetỏ a rehabilitált negyedek, 
Kovács Zoltán - Szirmai Viktória : Városrehabilitációs beavatkozások és a térbeli társadalmi kirekesztés :

A társadalmilag fenntartható városfejlődés budapesti lehetőségei. Tér és Társadalom 20. évf. 2006/1. 1-19. p.

övezetek számának a gyarapodása is. Ezek különbözỏ modellek szerint jönnek létre, többnyire az állami és a piaci szereplők együttmüködése eredményeként. A szociális típusú rehabilitációs modellek azonban inkább csak kísérletekként, tervekként jelennek meg. Ezért a kelet-közép-európai városokban általános probléma a városrehabilitáció lassú, szigetszerú kibontakozása.

A városközpontok lakóövezeteinek a felújítását akadályozza a helyi önkormányzatok kedvezötlen anyagi helyzete, amely nem elegendő átfogó rehabilitációs projektek megvalósításához. Nehézségeket okoznak a lakásprivatizációs modellek is, a kelet-közép-európai városi népesség többsége lakástulajdonos, akik anyagi helyzetuik alapján többnyire képtelenek a házak és lakásaik felújítására. A társadalmi polarizáció éleződése, a jövedelmi differenciák emelkedése szintén akadályozzák a magánerő bevonását a rehabilitációs projektekbe.

A poszt-szocialista városokban az 1990-es évek során a felsőbb rétegek visszaáramlása is megfigyelhetövé vált. A piaci viszonyok között megvalósuló rehabilitált lakótömbök felújított, drága és komfortos lakásait, az újonnan épített lakásokat a tehetősebb rétegek foglalták el. A belvárosi környezet igen vonzónak bizonyult a globális elit képviselői számára is. A globális trendeknek megfelelöen a városcentrumokban (is) laknak a multinacionális cégek nemzeti és külföldi menedzserei, magasan képzett szakemberek.

A nyugat-európai trendeknek megfelelóen a kelet-közép-európai nagyvárosi térségek alacsonyabb társadalmi státuszú csoportjai egyrészt a városok belsỏ övezeteiben, a leromlott negyedekben, a slumokban és az alacsony státusú lakótelepeken, másrészt a rosszabb minőségú külső városrészekben, illetve a kedvezőtlen ökológiai és infrastrukturális pozíciójú városkömyéki településeken jelennek meg (Lichtenberger et al. 1995, 150; Szirmai 2004).

\section{A társadalmilag fenntartható városfejlödés kihívásai Budapesten}

Budapest térbeli társadalmi szerkezete történetileg a centrum-periféria modell szerint alakult (Csanádi-Ladányi 1992). A városegyesítést követő idószakban a magasabb jövedelmủ és társadalmi státuszú csoportok a belsỏ városrészekben, a szegényebb, alacsonyabb státuszú rétegek az 1950 elötti (Kis-) Budapest külterületein, az ipari városrészekben és peremtelepüléseken helyezkedtek el (pl. Köbánya, Angyalföld, Újpest stb.). Az államszocialista korszakban megkezdődött a centrum-periféria szerinti társadalmi egyenlőtlenségi modell módosulása. A hatvanas, hetvenes években épuilt első új lakótelepek magas státuszú népessége, valamint a belső városrészek hanyatló társadalmi presztízse megbontotta a korábban a centrumból kifelé haladva csökkenő státusz tendenciáját. A korábbiakhoz képest felgyorsult a budai hegyvidék benépesülése, amely egyre inkább az elit szegregációs szigetévé vált (1. ábra).

1990 után egyrészt tovább erősödött a budai hegyvidék elit-koncentráló szerepe, de emellett megjelentek, elsösorban a város közigazgatási határához igazodva új, magas státuszú lakónegyedek is, főként lakóparkok formájában. Míg a budai hegyvidék elöregedö társadalma a klasszikus (részben a régi szocialista) elit, addig a 
Kovács Zoltán - Szirmai Viktória : Városrehabilitációs beavatkozások és a térbeli társadalmi kirekesztés :

A társadalmilag fenntartható városfejlődés budapesti lehetőségei. Tér és Társadalom 20. évf. 2006/1. 1-19. p.

TÉT XX. évf. 2006

Városrehabilitációs beavatkozások és a ...

9

lakóparkok, „dzsentrisedett” városrészek az új technokrata elit lakóhelyét jelentik. Eközben erösödött az alacsony státuszú népesség szegregációja is. A társadalmilag hátrányos helyzetü csoportok, az alacsony iskolázottsággal és jövedelemmel rendelkezök, a munkanélküliek, a romák a legrosszabb ökológiai pozíciójú budapesti városrészekben, föként azokban a belvárosi negyedekben élnek, ahol a legrosszabb a lakásállomány, nagy a laksürüség, a lakások felszereltsége rossz, ahol Budapest ún. krízisterületei találhatóak (Városkutatâs $K f t$. 2004, 5). Az átmenet keretében tehát a piaci hatások, a telek- és lakásárak differenciálódása, a lakásszektor tulajdonviszonyainak átalakulása, a szociális bérlakásállomány privatizációja még markánsabbá tették a városközponti és a városperemi szegénységet (Lichtenberger et al. 1995, 150).

\author{
1. ÁBRA \\ A felsöfokú végzettségüek aránya 1990-ben \\ (Ratio of People with University or College Education in Budapest, 1990)
}

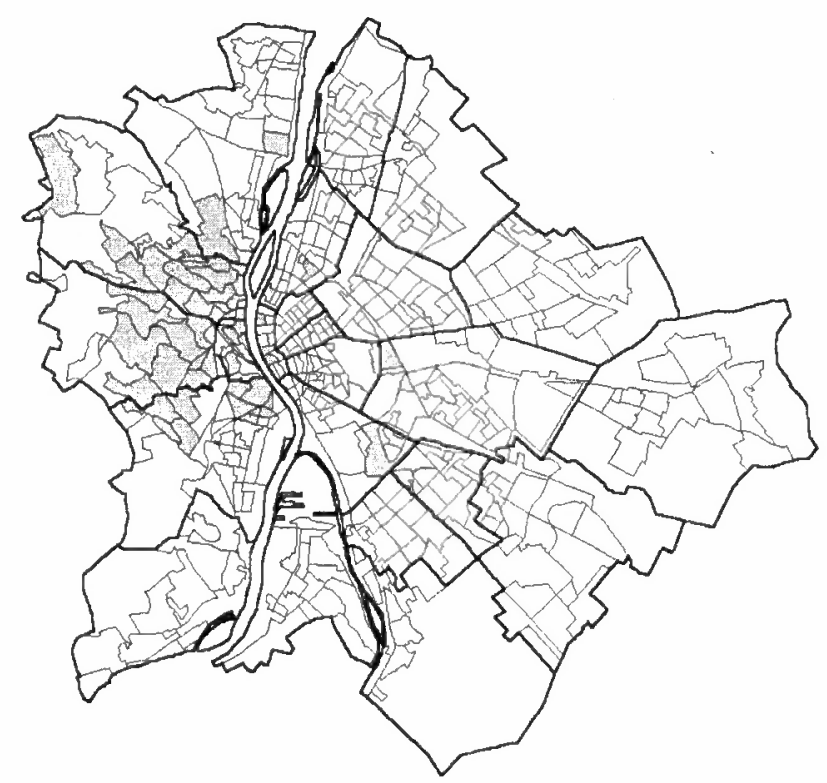

$20 \%$ alatt $20-25 \%$ $25 \%$ folott

Forrás: Saját szerkesztés.

A piacgazdasági átmenet nyomán fölerösödő társadalmi szegregáció nem csak a központi város, de a városrégió egésze szintjén is megfigyelhetővé vált. A Középmagyarországi régió (ennek keretében a budapesti agglomeráció) esetében is egyértelmü a felsőfokú végzettségüek egyre koncentráltabb elhelyezkedése (2. ábra). A régió központjában, vagyis a főváros belső részein, föként a budai övezetben a legmagasabb (30-50\%), a fôváros egyéb belsö részeiben is magas (10-30\%) a jelenlétük. A fövároson kívül (a szuburbanizációs folyamatok hatásait is tükrözve) az agglomerációs övezet északnyugati részén elhelyezkedô településeken is magas (10-30\%), a 
Kovács Zoltán - Szirmai Viktória : Városrehabilitációs beavatkozások és a térbeli társadalmi kirekesztés : A társadalmilag fenntartható városfejlődés budapesti lehetőségei. Tér és Társadalom 20. évf. 2006/1. 1-19. p.

régió perifériáján pedig a városrégió értékétől jelentősen elmarad (0-10\% között mozog) a felsőfokú végzettségủek aránya (A Közép-Magyarországi Régió 2003, 47).

\section{2. ÁBRA}

A felsőfokú végzettségüek aránya a megfelelö korúak százalékában (2001)

(Ratio of People with University or College Education in Central-Hungary, 2001)

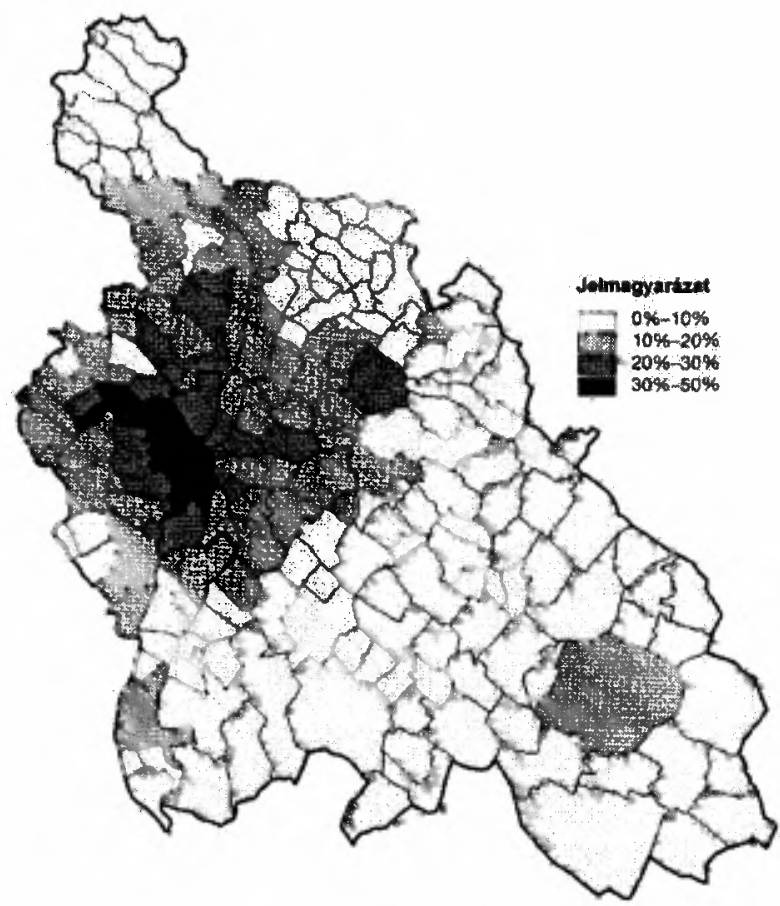

Forrás: Saját szerkesztés.

\section{A társadalmilag fenntartható városfejlödés fóbb akadályai Budapesten}

A Budapesten 1990 után kiépủlt kétszintü közigazgatás nem kedvezett sem a fenntartható városfejlődés, sem az átfogó rehabilitációs tevékenység számára. Gondot jelentett a kerületek kompetenciájának esetenkénti túlzott kiszélesítése (pl. a lakáspolitika terén), ami gyengítette a központi, egész várost érintő, átfogó programok megvalósítását. Fokozza a széttöredezett önkormányzati struktúrából fakadó hátrányokat, hogy a 23 kerület adottságai (épített környezet, társadalmi miliő stb.) és érdekei nagymértékben eltérnek egymástól. A differenciáltságok miatt nehezen szervezôdnek a konszenzusok.

Komoly gondot jelentett a különböző kormányok és Budapest nem megfelelő viszonya, az együttmüködés hiánya. Ez egyrészt minimálisra csökkentette az - ilyenkor egyébként joggal elvárható - központi támogatások esélyét. Másrészt arra kényszerít- 
Kovács Zoltán - Szirmai Viktória : Városrehabilitációs beavatkozások és a térbeli társadalmi kirekesztés :

A társadalmilag fenntartható városfejlődés budapesti lehetőségei. Tér és Társadalom 20. évf. 2006/1. 1-19. p.

TÉT XX. évf. 2006 -

Városrehabilitációs beavatkozások és a ...

11

tette a kerületeket és a fövárost, hogy feléljék azokat a tartalékokat, amelyekböl egy nagyobb léptékủ beavatkozás, a fizikai és társadalmi rehabilitáció elindítható lett volna.

Budapest környezeti adottságai sem kedveznek a fenntartható fejlődésnek. A zsúfolt és elavult belső lakónegyedek zömmel a pesti oldalra koncentrálódnak, amihez csupán egy karnyújtásnyi távolságra fekszik a zölddel gazdagon átszőtt, magas színvonalú lakókörnyezetet kínáló budai hegyvidék. Ez a jobbmódú lakosság erőteljes szegregácioját okozta. Hátrányt jelent az is, hogy a korábbi Kis-Budapest közigazgatási határához illeszkedő, fóként ipari és közlekedési (ill. raktározási) tevékenységeknek, valamint más nagy térigényü intézményeknek (temetök, laktanyák stb.) teret adó zóna erősen lepusztult, ,alulhasznosított” övezetté vált. A „,barnaövezet" súlypontja szintén a pesti oldalon található, s az 1950-es csatolások következtében belső választóvonalat, „puffer-zónát” képez a várostesten belül a bérházas öv és az egykori elỏvárosok öve között. A „barnaövezet” feljavítása továbbra is várat magára, bár elszórt pozitív példák már így is akadnak (pl. Váci út, Óbudai Gázgyár területe stb.) (Barta 2004).

A föváros társadalmilag fenntartható fejlödését akadályozzák az 1980-as évek óta jellemzö demográfiai trendek is. Budapest társadalma (a többi európai metropoliszhoz hasonlóan) nagymértékben elöregedett. A 60 éven felüliek aránya a város népességén belül az 1990-es 19,8\%-ról 2001-re 21,8\%-ra nőtt. Az eltartott gyermek nélkuili háztartások aránya 2001-ben itt volt a legmagasabb az országban, 68,1\%. (A falvakban ez az érték átlagosan csak 59,1\%). A túlzott elöregedés (és az elvándorlás) következtében a főváros lakosságszáma 1990 és 2001 között 244 ezer fövel (14,3\%) csökkent. Az elöregedő és fogyó társadalom a városrehabilitációra is negatív hatással van, hiszen az időskorúak beruházási kedve, s legföként anyagi lehetöségei meglehetösen behatároltak (3. ábra).

\section{3. ÁBRA}

A 14 év alatti és 60 év fölötti korcsoport a ránya Budapesten

(Proportion of Age Groups under 14, and 60+ within the Total Population in Budapest)

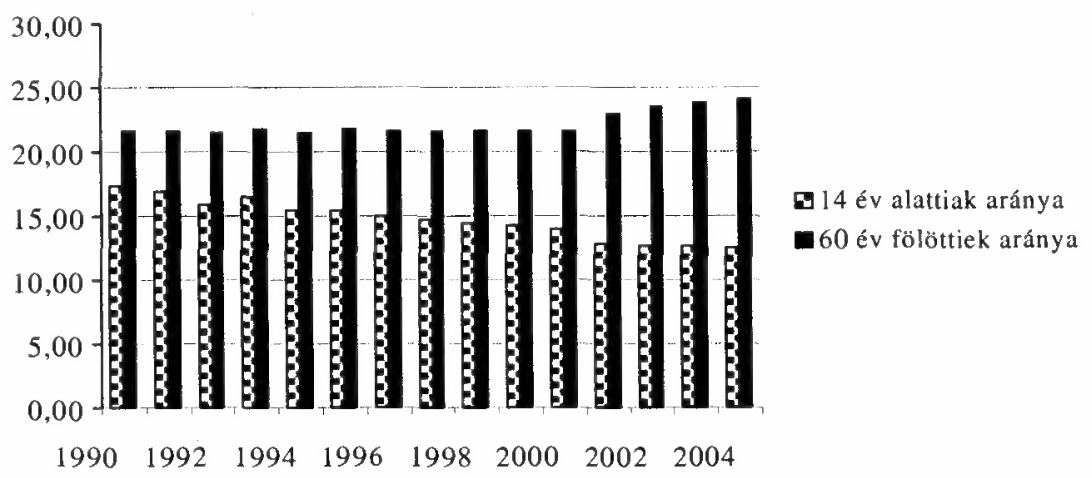

Forrás: Saját szerkesztés. 
Kovács Zoltán - Szirmai Viktória : Városrehabilitációs beavatkozások és a térbeli társadalmi kirekesztés :

A társadalmilag fenntartható városfejlődés budapesti lehetőségei. Tér és Társadalom 20. évf. 2006/1. 1-19. p.

A kiegyensúlyozott és társadalmi szempontból fenntartható városfejlődés ellenében hatott a népesség fajlagosan alacsony lakásmobilitása is. Az alacsony lakásmobilitási ráta hátterében a lakáspiac torz szerkezete, a bérlakásszektor csekély súlya, illetve a magánlakások túlsúlya éppúgy szerepet játszik, mint a társadalom elöregedése, vagy a lakáshitelezés késöi és vontatott megjelenése. Az alacsony mobilitási hajlandóság nem kedvez a rehabilitációnak, hiszen annak elengedhetetlen kelléke a népesség „egészséges” fluktuációja az egyes lakástípusok és lakónegyedek között. Kedvezőtlen jelenség az is, hogy a városrégión belül a lakásmobilitás egyoldalúan az elővárosi övezetbe irányult. Miközben a főváros népességszáma 1990 és 2001 között 14,3\%-kal csökkent, addig az agglomerációs övezeté 18,9\%-kal, 566 ezer föröl 674 ezer fóre nött. A népesség egyre gyorsuló ütemủ dekoncentrációja révén 1990 és 2001 között megváltozott a városrégió belső népesedési egyensúlya is. 1990-ben az agglomerációs öv részesedése a városrégió népességéböl 22\% volt, ez az érték 2001-re 27,6\%-ra emelkedett. A városrégión belüli vándorlás, a szuburbanizáció klasszikus modelljének megfelelően szelektív volt, ami a népesség demográfiai és társadalmi összetételét is átrendezte. A szuburbán öv az elmúlt másfél évtizedben folyamatosan fiatalodott, és státusza egyre emelkedett, miközben Budapest öregedett.

S végül nem felelnek meg a fenntartható városfejlödés kritériumainak az 1990 után létrejövő lakáspiaci feltételek sem. A város átfogó és összehangolt rehabilitációjához szükség van az egész városra kiterjedö programokra, lakáspolitikai beavatkozásokra. Az 1990-es önkormányzati törvény, illetve ennek budapesti adaptációja éppen ennek feltételeit szüntette meg. Azzal ugyanis, hogy a törvény a lakáspolitikát kivette a főváros kezéből, és a kerületekhez rendelte egyszeriben 22 (majd Soroksár létrejöttével 23), egymástól eltérő lakáspolitika kereteit teremtette meg. Ez megpecsételte a kerületek által örökölt bérlakásállomány további sorsát, a városrehabilitáció gyakorlatát, a lakásépítés feltételeit, s végső soron Budapest lakáspiacának további fejlödését.

A lakáspiac 1990 utáni átalakulására a korábbi állami szektor gyors ütemü privatizációja gyakorolta a legnagyobb hatást. A Budapesten megvalósított lakásprivatizáció miatt az egykor négyszázezret számláló állami bérlakás-szektorból 2002-re 74 ezer maradt, az összes lakásállomány kevesebb, mint 10\%-a.

Tovább fokozta a gondokat, hogy a privatizáció során az önkormányzatok bérlakásvagyonuk komfortosabb és nagyobb, ennél fogva értékesebb részét ,árusították ki". A megmaradt állami bérlakások többségét kis alapterületủ, alacsony komfortfokozatú, erősen leromlott lakások alkotják, amely egyre inkább egy szociálisan hátrányos helyzetủ, nagyfokú társadalmi kirekesztettségben élő réteg számára jelent hajlékot. Az 1990-es évtized lakáspolitikája tehát sokkal inkább a nagyvárosi problémák (a szegregáció, a gettósodás stb.) fölerösödéséhez, mintsem az enyhítéséhez járult hozzá. 
Kovács Zoltán - Szirmai Viktória : Városrehabilitációs beavatkozások és a térbeli társadalmi kirekesztés :

A társadalmilag fenntartható városfejlődés budapesti lehetőségei. Tér és Társadalom 20. évf. 2006/1. 1-19. p.

TÉT XX. évf. 2006 - 1

Városrehabilitációs beavatkozások és a ...

13

\section{A Budapesten megvalósitott rehabilitációs beavatkozások és társadalmi hatásaik}

Az 1990-es évek elejétöl tartó átalakulás Budapesten a városközpont, a belső városrészek látványos fejlődését, a city-képződést, illetve a város perifériájának dinamikus átrendeződését adta. Új vállalkozási területek, kereskedelmi és szolgáltató központok, bevásárlóközpontok, logisztikai centrumok, (többnyire) magas presztízsủ új, szuburbán lakóterületek, elegáns lakóparkok jelentek meg (Kovács-Sági-Dövényi 2001).

Budapest rendszerváltozás utáni legdinamikusabb városnegyedeit bemutató térkép alapján megállapítható, hogy a dinamikusan megújuló, illetve fejlődő negyedek elsösorban a város közigazgatási határához közel esó területeken találhatók (4. ábra) . $^{3}$. Ezek olyan, korábban alulhasznosított vagy mezőgazdasági hasznosítású terek, amelyeket a magas státuszú népesség igényeit kielégítő lakópark-építési hullám érintett.

\section{4. ÁBRA}

Budapest megújuló városrészei 1990-2001

(Upgrading Neighbourhoods in Budapest, 1990-2001)

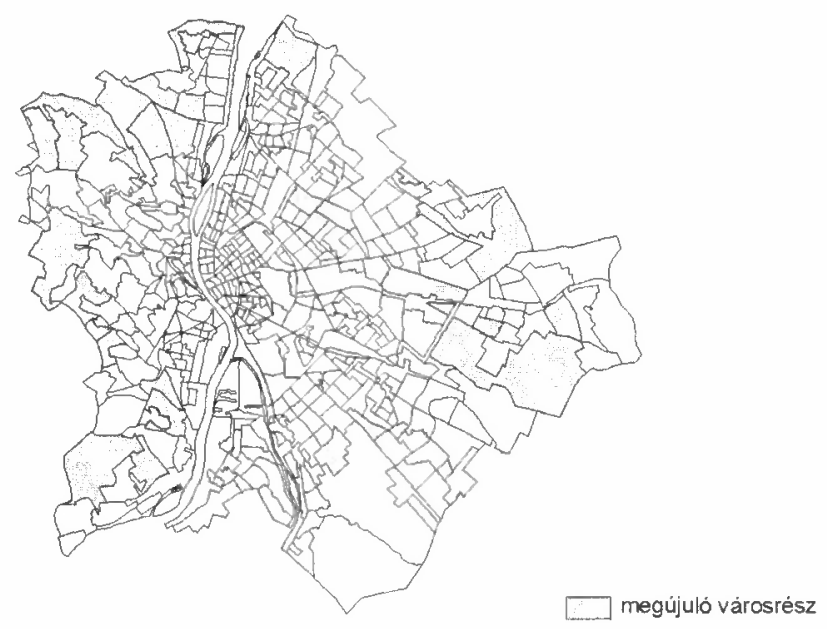

Forrás: Saját szerkesztés.

A belvárosban, a belvárost környezö lakónegyedekben ugyanakkor számos fizikai és társadalmi probléma koncentrálódik. Ezek mára jórészt lepusztult városrészek, elavult múszaki állapotú épületekkel, elhanyagolt közterületekkel, ahol alacsony státuszú, idősebb lakosság él, köztük egyre több a szegény, a munkanélküli, az underclass-hoz tartozó. A fizikai és a társadalmi leromlás azonban nemcsak a belsó városrészekben jelenik meg, hanem a lakótelepeken is. A lakótelepek között jelentös különbségek adódnak a városon belüli ökológiai státus, a fizikai jellegzetességek, a lakónépesség társadalmi összetétele és a lakások ingatlanpiaci helyzete alapján (Csizmady 2003, 264). 
Kovács Zoltán - Szirmai Viktória : Városrehabilitációs beavatkozások és a térbeli társadalmi kirekesztés :

A társadalmilag fenntartható városfejlődés budapesti lehetőségei. Tér és Társadalom 20. évf. 2006/1. 1-19. p.

A rendszerváltozással bekövetkezö politikai, gazdasági és társadalmi változások átrendezték a városrehabilitáció budapesti feltételeit is. Az 1990. évi LXV. Törvény (az Önkormányzati Törvény) újraszabályozta a fóváros és kerületeinek viszonyát, a rehabilitációval kapcsolatos tevékenységet a kerületek hatáskörébe utalva. Megkezdödött az állami bérlakások privatizációja, a szanálásra váró negyedek lakóinak jelentôs része bérlöböl tulajdonossá vált, $\mathrm{s}$ kialakultak a szabad ingatlanpiac feltételei. Ezzel egy idöben megjelentek és egyre nagyobb súlyra tettek szert a városrehabilitáció megvalósitásában részt vevő gazdálkodó szervezetek, profitorientált fejlesztési társaságok. A Fővárosi Közgyülés 1993-ban határozatban fogadta el a „Budapest reneszánszáért” címủ javaslatot, s kidolgozta a városrehabilitációhoz szükséges jogi, pénzügyi és szervezeti feltételrendszert. 1994-ben rendeletileg létrehozták a Fővárosi Városrehabilitációs Keret pályázati rendszerét, amely lökést adott a kerületeknek helyi rehabilitációs stratégiáik kidolgozásában, s saját rehabilitációs tevékenységük intézményi feltételeinek megteremtésében.

Fordulat következett be a városrehabilitáció értelmezésében is, hiszen míg korábban rehabilitáció alatt csak a belsỏ lakónegyedek felújitását értették, addig Budapest 1997-ben megfogalmazott rehabilitációs programja már kiemelt rehabilitációs feladatnak tekintette a korábbi iparterületek, valamint a lakótelepek felújítását is.

Mindez a lehetséges rehabilitációs alternatívák és stratégiák mozaikos sokszínüségét eredményezte Budapesten. A kerületek városfejlesztésben betöltött pozícioja a fövárossal szemben megerösödött, mind a tervezés, mind a gyakorlati megvalósítás terén. Az elképzelés szerint a városrehabilitáció uigye az egész várost érinti, így annak finanszírozásában a kerületek mellett a Fóváros is részt vesz (a költségek 50\%-ával). Ehhez azonban több kritériumnak is teljesülnie kell, pl. rendelkezzen a kerület rehabilitációs stratégiával, konkrét kijelölt akcióterülettel, ill. a helyi lakásprivatizációból befolyó összeg 50\%-át fizesse be a Fővárosnál külön erre a célra felállított kasszába. A városrehabilitáció a kilencvenes évek végén - a már hatékonyan zajló beavatkozásokat, pl. SEMIX, Rév8, leszámítva - csak akadozva indult be, s átütó eredményeket máig nem hozott. Legalábbis nem nevezhető sikeresnek a budapesti városrehabilitáció abból a szempontból, hogy a rehabilitációra ,érett”, mintegy 250 ezer lakásból, a rendszerváltás óta alig 5 ezret (kb. $2 \%$ ) sikerült felújítani, vagy újra „lecserélni” (bontással, építéssel). Ennek túlnyomó része is egyetlen területre, a Középső-Ferencvárosra koncentrálódik (Egedy et al. 2002).

Nem tekinthetỏ sikeresnek a fövárosi rehabilitáció azért sem, mert az eddig megvalósított rehabilitációs programokban minden esetben csak az épületállomány megújulására, kicserélödésére került sor, miközben a társadalmi érdekek, a helyi kulturális értékek és hagyományok súlyosan sérültek. Az ismert beavatkozások az érintett területek ingatlanpiaci felértékelődéséhez, egyszersmind a lakosság gyors kicserélödéséhez vezettek. Közös jellemzöjük a piaci alapú, vállalkozó tőke túlsúlya, és a közszféra korlátozottabb szerepvállalása. Ez a dzsentrifikációs nyomás fölerösödését adta. Az eredeti népesség lecserélődése, az épületállomány drasztikus átalakítása az eredeti miliỏ radikális megváltozásához vezetett (Városkutatás Kft. 2004). 
Kovács Zoltán - Szirmai Viktória : Városrehabilitációs beavatkozások és a térbeli társadalmi kirekesztés :

A társadalmilag fenntartható városfejlődés budapesti lehetőségei. Tér és Társadalom 20. évf. 2006/1. 1-19. p.

TÉT XX. évf. 20061

Városrehabilitációs beavatkozások és a ...

15

Ennek alapján több szakértő azt javasolja, hogy a piaci orientációjú városrehabilitáció programokat az ún. szociális városrehabilitáció eszközrendszerével kell kiegészíteni, amely a komplex jellegủ rehabilitációs problémára komplex válaszokat ad, közösségi pénzekböl úgy, hogy az ne vezessen a városrész lakosságának teljes kicserélődéséhez (Városkutatás Kft. 2004, 3-4). A föváros támogatta az elképzelést, s a Fővárosi Közgyủlés 2005 januárjában döntést hozott a budapesti városrehabilitációs programon belül, úgynevezett „,szociális városrehabilitációs" modell kísérletek elindításáról. A négy évig tartó, mintegy 1,8 milliárd forinttal megvalósuló program legfontosabb célja, hogy az alacsony társadalmi státusú, szegregált lakónegyedek fizikai megújulása egy erőteljes szociális programmal társulva érje el, hogy a helybeliek társadalmi kirekesztettsége oldódjon, s a rehabilitációs beavatkozás végén a lakosság legalább 70\%-a továbbra is helyben maradjon. A modellkísérlet első szakasza három mintaterület szociális rehabilitációjával számol: a józsefvárosi Magdolna-negyeddel, Kőbányán a Bihari úti szegényteleppel és a ferencvárosi „Dzsumbuj” negyeddel (Illatos út). A fizikai rehabilitáció és a társadalmi kohézió erősítésének gondolata, illetve a kettő összekapcsolása nem magyar ötlet. Nyugat-Európa nagyvárosaiban számos olyan sikeres beavatkozási módszert találunk, amelyek hazai adaptálása, a kétség kívül meglevő társadalmi-gazdasági különbségek ellenére lehetséges (Holt-Jensen et al. 2004).

A budapesti helyzetértékelésböl számos, általános érvényü következtetés is levonható:

- Egyrészt az, hogy a városfejlődés általános folyamatai és a társadalmi egyenlötlenségek szorosan összefüggenek egymással.

- Másrészt az, hogy a társadalmi kirekesztettség, a szegénység elsősorban a belváros közeli bérházas negyedekbe, az egykori ipari zóna (barnaöv) lakófunkciójú zárványaira, valamint a lakótelepekre koncentrálódik, bár a városkörnyéki szegénység is növekszik.

- Harmadrészt az, hogy a társadalmi kirekesztés folyamatát, közte az alacsony státuszúak városcentrumokból való kiszorulását alapvetően makrogazdasági, térbeli társadalmi folyamatok magyarázzák, de a mai rehabilitációs mechanizmusok (politikák és stratégiák) szerepe sem elhanyagolható. A rehabilitáció kiterjesztését, a fenntartható társadalomfejlődést számos társadalmi, gazdasági és lakáspiaci-lakáspolitikai tényező akadályozza, és a várospolitikai hatások sem mindig pozitívak.

- Negyedrészt az, hogy a társadalmilag fenntartható rehabilitáció nemcsak a belváros problémája, egyéb olyan városrészek (közte a lakótelepek) is ki vannak téve a fizikai és társadalmi hanyatlás kedvezőtlen hatásainak, a térbeli társadalmi problémák és konfliktusok koncentrációjának.

- Végül pedig az, hogy a városrészek fizikai és társadalmi leromlása, a térbeli társadalmi egyenlötlenségek növekedése miatt a belvárosi övezetek lakosságán kívül más területi csoportok is veszélyeztettek, de ökológiai és társadalmi pozícióik alapján, differenciált módon. 
Kovács Zoltán - Szirmai Viktória : Városrehabilitációs beavatkozások és a térbeli társadalmi kirekesztés :

A társadalmilag fenntartható városfejlődés budapesti lehetőségei. Tér és Társadalom 20. évf. 2006/1. 1-19. p.

\section{A társadalmilag fenntartható városrehabilitáció kialakitására vonatkozó javaslatok}

A fizikai és társadalmi rehabilitációnak számos típusa lehet (Városkutatás Kft. 2004). A típusok szerveződéseit a beavatkozás kezdeményezői, a piaci és a hatósági jelenlét arányai, a privát és a közösségi források megosztása, valamint az érintett lakossági szereplók részvétele (munkamegosztása) határozza meg. Az elmúlt másfél évtizedben Magyarországon fóként a piaci orientáltságú és kisebb részben a szociális irányultságú rehabilitációs formák léteztek.

A fóvárosban elkezdett szociális rehabilitáció szükséges, de nem elégséges eszköze a városi lakónegyedek fizikai és társadalmi felújításának, a további leromlás megakadályozásának. A szociális rehabilitáció felfogásán alapuló városfelújítási stratégiảk csak a városok legsúlyosabb krízisterületeire és a legszegényebb társadalmi csoportokra terjednek ki, számos egyéb, fizikai és társadalmi értelemben ugyancsak leromlott (noha nem marginalizálódott) negyed és hátrányos helyzetü társadalmi csoport kimaradhat a hatásokból. Ez jövöbeni krízisterületek kialakulásához vezethet.

Az eddigi budapesti (és más városokban követett) stratégiák ,felülről kezdeményezett", az összes érdekelt bevonása nélkül megvalósuló beavatkozások, akár piaci, akár önkormányzati rehabilitációról van szó. Ezek a kezdeményezések nem voltak figyelemmel az érdekelt társadalmi (lakossági) csoportok eltérő érdekeire és lehetőségeire, a rehabilitációs problémák mögött talạlható differenciált társadalmi szerkezetre.

A magyar városok térbeli társadalmi problémáinak megoldásához megfelelöbbnek látszik a fizikai és a társadalmi rehabilitáció egy olyan típusa, amely a piaci és a hatósági, valamint az érintett lakossági szereplők közös és aktív részvételén alapszik. Ahol az alá- és fölérendeltség helyett a kölcsönös kapcsolatokon és kommunikáción, a privát és a közösségi források érintettek helyzete szerinti megosztásán és felhasználásán van a hangsúly. A fizikai és társadalmi rehabilitáció differenciált felfogása alapján, várostípusonként, városrészenként, azok fizikai állapota és a lakosság társadalmi összetétele (és anyagi helyzete), továbbá a kapcsolódó érdekek szerkezete szerint is differenciált felfogásokat, eltéró értelmezést és koncepciókat, ennek alapján differenciált stratégiákat és konkrét projekteket célszerü kidolgozni. A továbblépéshez városrészenként, társadalmilag differenciált rehabilitációs politikák kialakítására van szükség.

Az eddigi rehabilitációs beavatkozások kedvezótlen társadalmi következményei és az érdekek érvényesülése alapján, továbbá a szociális rehabilitáció kritikai elemzése alapján javasoljuk a társadalmi részvételre alapozott rehabilitáció megvalósítását. A társadalmi részvételre alapozott rehabilitáció célja a társadalmi, gazdasági és környezeti egyenlötlenségek kumulatív hatásainak kezelése, a városrészek komplex, társadalmi konszenzuson alapuló felújítása, és a társadalmi konfliktusok enyhítése, a helyi társadalmi integráció (a kohézió) erösítése.

A társadalmi részvételre alapozott rehabilitáció a legkomplexebb rehabilitációs típus. Felfogásunk szerint a társadalmilag fenntartható városrehabilitáciǒ megvalósításának a legfóbb eszköze. Ez a stratégia az összes érintett és érdekelt szereplő részvé- 
Kovács Zoltán - Szirmai Viktória : Városrehabilitációs beavatkozások és a térbeli társadalmi kirekesztés :

A társadalmilag fenntartható városfejlődés budapesti lehetőségei. Tér és Társadalom 20. évf. 2006/1. 1-19. p.

TÉT XX. évf. 2006

Vảrosrehabilitációs beavatkozások és a ...

17

telére és kooperációjára épít, és biztosítja a társadalmilag fenntartható városfejlödést, vagyis azt, hogy a lakosság és hatóság, valamint a kapcsolódó aktorok közös és egyeztetett anyagi lehetőségeik, szükségleteik és érdekeik alapján, tárgyalások keretében döntsếk el a felújitásra kerülő városrész és az ott élők rövid és hosszú távú jövőjét.

Ennek megvalósulása azonban a hatalmi (közszféra) és civil szféra új, egyenrangú és kölcsönös viszonyát, a globălis gazdaság szereplöi és a nemzeti, városi politikai aktorok, valamint a civil szféra partnerségét, ezáltal társadalmilag megalapozott városfejlesztési mechanizmusokat, a társadalmi érdekérvényesítés intézményeit, vagyis új elosztási és döntési rendszereket feltételez.

Szükséges, hogy a rehabilitációs beavatkozások és a szabályozások vegyék figyelembe az adott vărosrész(tömb) városrégióban, illetve a nagyváros egészében (ökológiai szerkezetében) elfoglalt helyzetét, a városfejlödẻsi hierarchiában elfoglalt pozíciójảt (a gazdasági és intézményi, infrastrukturális megújulásra való képességét). Továbbá az érintett lakosság társadalmi strukturális helyzetét, a társadalmi hắtrányokat és előnyöket, a megújulásra, az innovációra való ökológiai és társadalmi képességét. Nézzék meg, hogy a két szerkezetnek milyen az egymáshoz való viszonya, hogy a problémákat kumulatív módon erősítő vagy éppen enyhítő hatásokról van szó. A megoldás érdekében a szabályozásokat megalapozó kutatások tárják fel az elkülönülő tényezőket, a kapcsolódási pontokat is.

A rehabilitációs beavatkozások és a szabályozások vegyék figyelembe az érintett és érdekelt társadalmi csoportok ökológiai és társadalmi pozícióit, az előnyöket és a hátrányokat, a mobilizálható tényezőket, (humán erőforrásokat, pénzügyi lehetőségeket), a beavatkozások által képviselt és a kimaradt társadalmi csoportok érdekeit, és tegyenek javaslatot a konfliktuskezelés eszközeire, az érdekérvényesítés mechanizmusaira. A megvalósításhoz szükség van az érdekellentmondások feltárására, az érdekek tisztázásăra, a konfliktuskezelés intézményeinek és módszereinek a kialakítására, az érdekeltek participációját biztosító intézmények, kapcsolódó szervezetek megteremtésére is.

A társadalmi fenntarthatóságot szolgáló fizikai és tắrsadalmi rehabilitációs beavatkozások nem valósíthatók meg a tervezés és az érintett tărsadalmi csoportok kapcsolatai nélkül. De nem valósíthatók meg a tervezésben részt vevỏ szakmacsoportok együttmúködése nélkül sem. Ez utóbbiakat ma sokkal inkább jellemzik a konfliktusok, mint az együttmúködés. A megvalósítás lehetöségeit adják a létező szabályozások társadalmi hatăsvizsgálatai, a szabályozások társadalmi összefüggéseinek, az érintett és érdekelt szereplőknek a tervezésbeli integrálása, egy ún. integrált rehabilitációs tervezési gyakorlat, szakmai kooperáció megteremtése. Mindez a tervezés új funkcióit, a hatalmi és a társadalmi szféra közötti közvetítés valóságos mechanizmusait, vagyis a tervezés modernizációját, a társadalmilag megalapozott tervezés gyakorlatát eredményezné. 
Kovács Zoltán - Szirmai Viktória : Városrehabilitációs beavatkozások és a térbeli társadalmi kirekesztés : A társadalmilag fenntartható városfejlődés budapesti lehetőségei. Tér és Társadalom 20. évf. 2006/1. 1-19. p.

\section{Jegyzetek}

1 A tanulmány átdolgozott változata Szirmai V.-Kovács Z.: „A társadalmilag fenntartható városfejlődés szempontjainak érvényesítése a speciális rehabilitációs szabályozást igénylö fövárosi terủleteken Budapesten” címü tanulmánynak. Ez a tanulmány „A fenntartható városfejlődés szempontjainak érvényesítése a speciális rehabilitációs szabályozást igénylö fövárosi terủleteken" címú MUT projekt keretében készült.

${ }^{2}$ Kovács Zoltán geográfus, az MTA Doktora, (MTA Földrajztudományi Kutatóintézet, 1112 Budapest, Budaörsi út 45.) h3971kov@helka.iif.hu, Szirmai Viktória, szociológus, az MTA Doktora (MTA Szociológiai Kutatóintézet, 1014 Budapest Úri u. 49. h9579szi@ella.hu.

3 Budapest legdinamikusabb városrészei társadalomstatisztikai adatokon alapuló vizsgálatá során figyelembe vett mutatók: 1.) A népességszám változása 1990-2001 között; 2.) A diplomások arányának változása 1990-2001 között; 3.) Az 1990 és 2001 között épült lakások aránya;. 4.) A fürdószobás lakások arányának változása 1990-2001 között.

\section{Irodalom}

Barta Gy. (szerk.) (2004) A budapesti barnaövezet megújulási esélyei. MTA Társadalomkutató Központ, Budapest.

Brundtland, G.H. (1987) Közös jövönk. Mezögazdasági Kiadó, Budapest.

Berger, L.R. (1998) Integration, errances e résinstences urbaines. - Haumont, N. (ed.) L'Urbain dans tous ses étas, Faire, vivere, dire la ville. Paris, L'Harmattan. 269-283. o.

Csanádi G.-Ladányi J. (1992) Budapest térbeni-társadalmi szerkezetének változásai. Akadémiai Kiadó, Budapest.

Csizmady A. (2003) A lakótelep. Gondolat, Budapest.

Egedy T.-Kovács Z.-Székely J.-Szemzö H. (2002) Városrehabilitációs programok eredményei és tapasztalatai Budapesten. - Falu Város Régió. 8. 3-10, o.

Enyedi Gy. (2003) Városi világ - városfejlödés a globalizáció korában. Pécsi Tudományegyetem Közgazdaságtudományi Kara, Regionális Politika és Gazdaságtan Doktori Iskola, Pécs.

Fleischer, T. (2002) Prospects of an Eco-City Development in the Central and Eastern European Urban Areas. Institue for World Economics of the Hungarian Academy of Sciences.

Hancock, T. (2004) The „Soft Infrastructure" of the Healthy Community. - New City Journal. www.newcity/pages/social-sustainability.html.

Hermann, M.-Leuthold, H. (2005) The Consequences of Gentrification and Marginalisation on Political Behaviour. www.sotomo.geo.unizh.ch/papers.

Holt-Jensen, A. et al. (eds) (2004) New Ideas for Neighbourhoods in Europe. Handbook, TUT Press, Tallinn.

Hoyt, H.A. (1973) A városi struktúra klasszikus modelljének újabb torzulásai. - Városszociológia. Szelényi 1. (szerk.) KJK, Budapest. 61-182. o.

Innovative policies for sustainable urban development. (1996) The Ecological City.

Kovács Z. (2002) Az urbanizáció jellemzöi Kelet-Közép-Európában a posztszocialista átmenet idején. - Földrajzi Közlemények. 1-4. 57-78. o.

Kovács Z.-Sági Zs.-Dövényi Z. (2001) A gazdasági átalakulás fóldrajzi jellemzöi a budapesti agglomerácioban. Földrajzi Értesítő 1-4. 191-217. o.

A közép-magyarországi régió társadalmi atlasza. (2003) Pro Régió Ügynökség, Budapest.

Lichtenberger E.-Cséfalvay Z.--Paal M. (1995) Várospusztulás és felújítás Budapesten. Magyar Trendkutató Központ.

Martinotti, G. (2004.) The new social morphology of cities. Discussion Paper Series, No.16. inequalities of the european urban regions/UTI.

Musil, J. (2002) Changing urban system in post communist societies in Central Europe. - Pacione, M. (ed.) The City - Critical Concepts. Routledge, New York, London.

Sassen, S. (1991) The Global City. New York, London, Tokyo. Princeton University Press, Princeton, New Yersey.

Sóoki-Tóth G. (2005) Városrehabilitáció az Európai Unióban. - Egedy T. (szerk.) Városrehabilitáció és társadalom. MTA Földrajztudományi Kutatóintézet, Budapest. 63-71. o.

Szirmai V. (1999) A környezeti érdekek Magyarországon. Pallas Stúdió, Budapest. 
Kovács Zoltán - Szirmai Viktória : Városrehabilitációs beavatkozások és a térbeli társadalmi kirekesztés : A társadalmilag fenntartható városfejlődés budapesti lehetőségei. Tér és Társadalom 20. évf. 2006/1. 1-19. p.

TÉT XX. évf. 2006 a 1

Városrehabilitációs beavatkozások és a ...

19

Szirmai V. (2004) Globalizáció és a nagyvárosi tér társadalmi szerkezete. - Szociológiai Szemle. 4. Budapest.

Szirmai, V.-Baráth, G. (2005) Global urban development in Budapest and the role of architecture. Barta, Gy.-G.Fekete, É.-Sz.Kukorelli, I.-Timár, J. (eds.) Hungarian Spaces and Places: Patterns of Transition. CRS HAS, Pécs. 434-448. o.

Tamás, P. (2006) Fenntartható Magyarország. Tankönyvkiadó, Budapest (Megjelenés alatt).

Timár J. (1999) Elméleti kérdések a szuburbanizációról. - Földrajzi Értesítö. 1-2. 7-31. o.

Territorial Development, Urban Policy in Germany, Towards Sustainable Urban Development. (1999) OECD.

Városkutatás Kft. (2004) A szociális városrchabilitáció: Koncepció, eszközrendszer és modellkísérletek. Zárótanulmány kézirat. Városkutatás, Budapest.

Veltz, P. (1996) Mondialisation villes et territoires. L'économe d'archipel, économie en liberté. Presses Universitaires de France.

\section{INTERVENTION OF URBAN REHABILITATION AND SPATIAL SOCIAL EXCLUSION: POSSIBILIES OF SOCIALLY SUSTAINABLE URBAN DEVELOPMENT IN BUDAPEST}

\section{ZOLTÁN KOVÁCS - VIKTÓRIA SZIRMAI}

The article deals with those European urban problems that require the implementation of the concept of a socially sustainable development as well as the spatial, social challenges in Budapest and the difficulties in the realisation of the socially sustainable urban development.

The analyses reveal the major social consequences of the different urban rehabilitation models in Budapest such as the changing population of the affected districts, the gentrification and the intensification of segregation processes. The article makes proposals for the establishment of a socially sustainable urban rehabilitation. 